\title{
Historical Files from Federal Government Mineral Exploration-Assistance Programs, 1950 to 1974
}

\section{http://minerals.usgs.gov/dockets/}

Congress enacted the Defense
Production Act in 1950 to provide
funding and support for the explo-
ration and development of critical
mineral resources. From 1950 to
1974, three Department of the Interior
agencies carried out this mission.
Contracts with mine owners provided
financial assistance for mineral explo-
ration on a joint-participation basis.
These contracts are documented
in more than 5,000 "dockets" now
archived online by the U.S. Geological
Survey. This archive provides access
to unique and difficult to recreate
information, such as drill logs, assay
results, and underground geologic
maps, that is invaluable to land and
resource management organizations
and the minerals industry.

\section{History of the Programs}

In 1950, Congress enacted the Defense Production Act, which authorized the President to make provisions for the encouragement of exploration, development, and mining of critical and strategic minerals, metals, and materials. The President delegated his authority to the Department of the Interior, among other agencies, and the Secretary of the Interior established the Defense Minerals Administration (DMA). The DMA provided U.S. Government support for exploration of unknown or undeveloped mineral deposits. To this end, the DMA established a program that would provide funds for projects that sought or developed sources of strategic or critical metals and minerals. When the DMA ended in November 1951, the Department of the Interior formed the

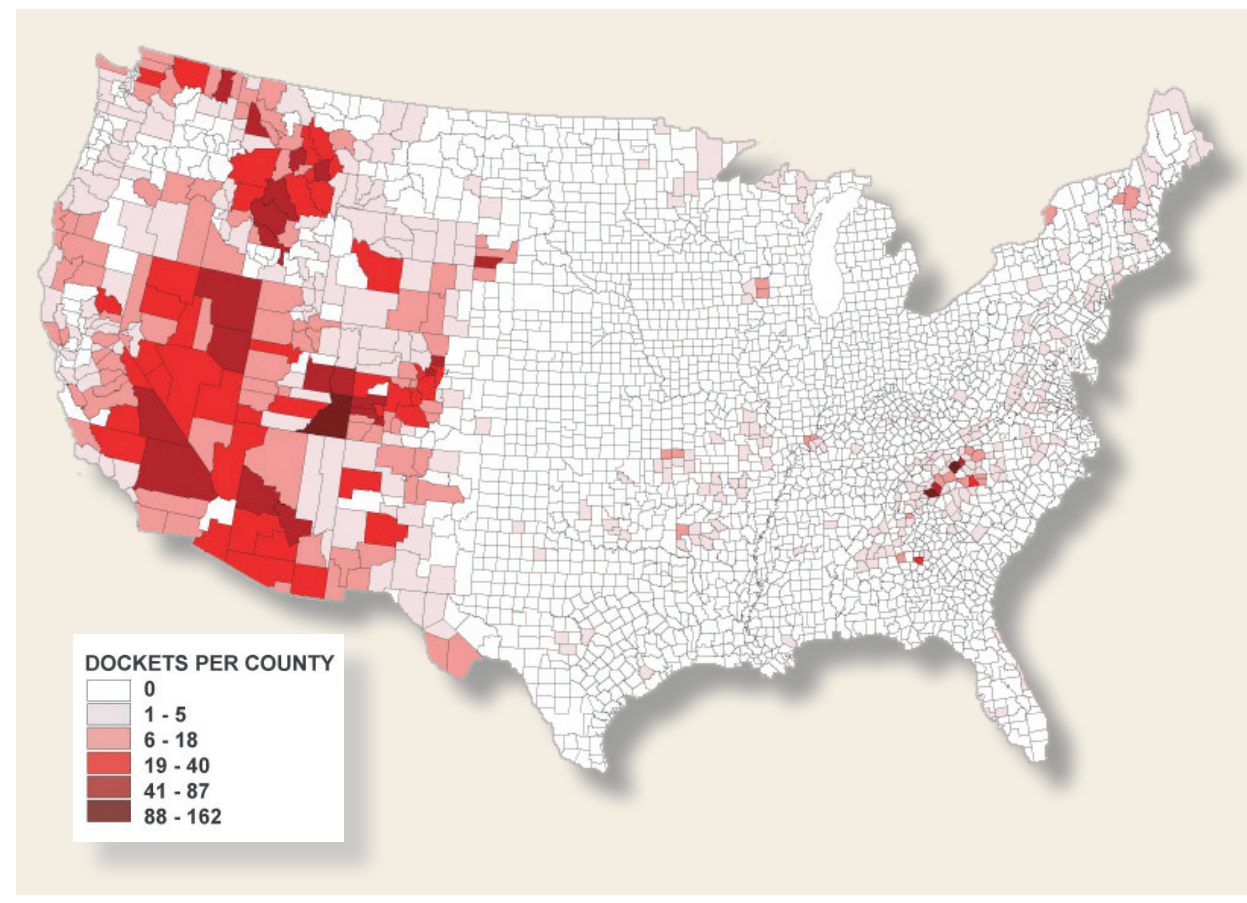

A new U.S. Geological Survey Web site (http://minerals.usgs.gov/dockets/) provides public access to files or "dockets" for Federally supported critical mineral exploration conducted form from 1950 to 1974. This map shows the number of dockets per county in the United States. The majority of site locations are in one of the 11 Western States.

Defense Minerals Exploration Administration (DMEA) and continued the program until June 1958. In August of that year, Congress authorized the Secretary of the Interior to provide financial assistance that would promote exploration for domestic mineral reserves, and the Secretary formed the Office of Minerals Exploration (OME). In 1965, OME was transferred to the U.S. Geological Survey (USGS), where it remained until Congress canceled funding in 1974. From 1950 to 1974 , contracts between mine owners and these agencies provided financial assistance for exploration on a joint-participation basis. These contracts are documented in more than 5,000 property files (called "dockets") generated by the DMA, DMEA, and OME exploration-assistance programs.

\section{History of the Files}

A master set of dockets was stored at Suitland, Maryland, and then transferred to the Spokane, Washington, office of the USGS in 1993. Files previously held at the USGS National Center at Reston, Virginia, and those formerly held at USGS field offices in Denver, Colorado, Menlo Park, California, and Knoxville, Tennessee, were also transferred to Spokane. A digital index to these files was created in 1997, and the USGS began to provide public access to the paper copies of dockets. Original docket material is composed of vintage 1950-70 era 
paper, carbon paper copies, mimeograph copies, blueline copies of maps, linen or mylar maps, and other fragile and sometimes poor quality media. These types of materials deteriorate over time as a result of normal aging, handling, and being duplicated. An effort to preserve the data began in 2009 , and the entire collection of dockets was electronically scanned. The scanning process used optical character recognition (OCR) when possible, and files were converted into Portable Document Format (.pdf) files, which require Adobe Acrobat Reader for viewing. In 2010, the scans were placed online (http://minerals.usgs. gov/dockets/index.htm) and are available to download free of charge.

\section{Docket Contents}

The first item in most dockets is a letter from an applicant requesting Federal Government assistance in exploring for minerals. The program application contains information concerning the property's location, mineral commodity (limited commodities were acceptable under the different Programs; see the Web site for a complete list of commodities by program), and funds requested. The next item is often a site evaluation, including recommendations, done by USGS or U.S. Bureau of Mines geologists. Additional reports might detail the ongoing status of the application, specifics of any financial contract awarded, results of exploration, production summaries, financial repayment schedules, interim evaluations, and contract completion data. The file size of a scanned docket is determined by the amount of information contained in the original paper docket and how many (if any) oversized maps are included in the scan.

\section{Area of Coverage}

The dockets reflect program activities carried out in 44 States. No applications were submitted for the States of Delaware, Indiana, Nebraska, North Dakota, Ohio, and Rhode Island. Published reports containing indexes for the entire collection and the four northwest States of Idaho, Montana, Oregon and Washington, are available online. The reports listed below contain property location and commodity information, as well as information about the Programs:

- All dockets—http://pubs.usgs. gov/of/2003/of03-94/

- Idaho-http://pubs.usgs.gov/ of/1997/ofro7439/

- Montana-http://pubs.usgs.gov/ of/1996/of96501/

- Oregon-http://pubs.usgs.gov/ of/1998/of98464/

- Washington-http://pubs.usgs. gov/of/1998/of98232/

\section{Scans of Dockets are Available Online}

Scanning resolution ranges from 600 to 1,200 dots per inch (dpi) depending on original document quality. Oversized maps were scanned at higher resolutions. Overall almost all documents are clear and legible. Scans include all docket material, including hand written notes and oversized maps that may have been hand drawn and colored. Using the "docket links" item in the menu bar at the top of http://minerals.usgs.gov/dockets/ index.htm provides quick access to tables containing links to the .pdf scans. Note the file size next to the property name. To download a scan simply select the link in the property name column. Download times for large files will vary depending on Internet connection speed, network traffic, and computer processor speed. The file size of the scanned dockets varies from less than 1 megabyte to nearly 500 megabytes, based on the amount of information the original docket contains and how many (if any) oversized maps are included in the scan. Under "Docket links" the "All by number" and "All by State" pages are large and will take some time to load. All docket numbers are unique, regardless of which Government program they were developed under.

\section{To view all dockets by State:}

From the "Docket links" menu select "All by number" or "All by State." A new Web page will open with a table showing an ordered list of all dockets by number (ascending order) or by State (alphabetical). The table contains hot links to the docket .pdf scans and lists the file sizes.

\section{To view the dockets by agency:}

From the "Docket links" menu select "All DMA," "All DMEA," or "All OME." A new Web page will open with a table showing an ordered list of all dockets for that program. The table contains hot links to the docket .pdf scans and lists the file sizes.

\section{To view dockets by individual Western State (sorted by County):}

From the "Docket links" menu select "Arizona," "California," "Colorado," "Idaho," "Montana," "New Mexico," "Nevada," "Oregon," "Utah," "Washington," or "Wyoming." A new Web page will open containing a table showing an ordered list of all dockets for that State, sorted by county. The table contains links to the docket .pdf scans and lists the file size. Files with no recorded State or county information can be viewed by selecting "No State ID."

The more than 5,000 historical minerals exploration-assistance dockets now archived online by the USGS provide access to unique or difficult to recreate data that is invaluable to land and resource management organizations and the minerals industry. Meeting the challenge of supplying America's needs for essential minerals requires accurate and unbiased scientific data. The ongoing work of scientists with the USGS Mineral Resources Program provides information crucial to the creation of sound policies that will ensure future supplies of mineral resources.

David G. Frank

Edited by James W. Hendley II Graphic design by Judy Weathers

\section{For more information contact: David Frank \\ U.S. Geological Survey 904 W. Riverside Ave., Room 202 \\ Spokane, WA 99201 \\ (509) 368-3107 \\ dfrank@usgs.gov \\ http://minerals.usgs.gov/}

This Fact Sheet and any updates

to it are available online at http://pubs.usgs.gov/fs/2010/3109/ 